\title{
時間配置と構造配置の融合による 活動プロセスの協働リフレクションの実現
}

\author{
友部 博教 $* 1 \cdot$ 中村 嘉志 $* 2 \cdot$ 沼 晃介*1・須永 剛司 $* 3 \cdot$ 西村 拓一 $* 2$
}

実世界に人々が集まり議論や創造的活動をするワークショップでは，活動プロセスの詳細を参加者や主 催者にフィードバックし, 自己や活動全体のリフレクション(振り返り)を誘発することが重要であると考 える。そこで本論文では，ワークショップにおける活動を，時間配置と構造配置による表現を融合するこ とによりリフレクションを支援する仕組み“ワークショップリフレクター”を提案する．ワークショップ中 に記録した写真やビデオを時間配置で表現する“タイムラインリフレクター”と, ワークショップ中のイベ ントをカードとして表現し構造配置する“カードリフレクター”を開発した。そして，ワークショップ中に 記録したデータをタイムライン上でリフレクションしながらイベントを切り出し，切り出したイベントを カードとして 2 次元上に構造的に配置していくことで, 活動プロセスをリフレクションする仕組みを実現 した。また，評価実験により時間配置による表現と構造配置による表現のリフレクションの効果を比較し た。その結果，活動プロセスの変遷のような時間的な変遷を捉える場合には時間的配置による表現が効果 的であり, 活動プロセスの関係性や構造化を振り返る場合には構造的配置が効果的であることがわかった. キーワード：リフレクション, ワークショップ, 活動支援, 時間配置, 構造配置

\section{1 . はじめに}

1960年代以降，世界中の様々な分野においてワー クショップと呼ばれる参加体験型の学習や創造活動の 場が広がりを見せている[1]。ワークショップを開催 する目的も様々であり，企業研修のグループワークの ように意見表出や問題解決のトレーニングとして利用 することや，地域住民が主体的にまちづくりの計画や 製作の策定を行う場として利用されることもある．近 年では特に，市民の表現活動や創作活動の活性化を目 的としたワークショップが盛んに開催されている。例 えば, CAMP (Children's Art Museum \& Park) ${ }^{* 1}$ や山 口情報芸術センター ${ }^{* 2}, \mathrm{CANVAS}^{* 3}$ などでは，子どもを 対象に創造性や表現力を引き出すワークショップを定期 的に提供している。 また海外でも，Capture Wales ${ }^{* 4}$ では映像を用いたストーリーテリングのワークショッ プを提供している。このようなワークショップを対象 に，参加者の創造性や表現力の向上だけでなく，体験

$\dagger$ Reflecting Processes of Human Activities on Workshops by Combining Timeline-based and Card-based Representation

Hironori TOMOBE, Yoshiyuki NAKAMURA, Kousuke NUMA, Takeshi SUNAGA and Takuichi NISHIMURA

*1 東京大学

University of Tokyo

*2 産業技術総合研究所

National Institute of Advanced Industrial Science and Technology

*3 多摩美術大学

Tama Art University
共有やコミュニケーションの活性化といった参加者同 士の相互作用を目指したアイデアも提案されている [2].

表現活動や創造活動を活性化するという文脈では, 自己の活動を認知的アプローチにより振り返ることが 有効である $[3]$ 。このような振り返りをリフレクショ ンと呼ぶまた，自己の活動を振り返って言語化する ことが学習を促進することが示されている [4]．表現 活動ということに焦点を絞ると，ワークショップのリ フレクションは以下の二つに分かれると考えられる.

・ワークショップで表現活動を行った，参加者自身 によるリフレクション

・ワークショップという表現の場を提供した，ファ シリテータ (司会進行役)たちによるリフレクショ ン

特に,ファシリテータはワークショップで重要な役 割を担う [5]。リフレクションによって，ファシリ テータたちが自分たちの活動を振り返りワークショッ プの進行上の良かった点, 悪かった点などを内省する ことを通じて，ファシリテータ自身のスキルを学習す

*1 http://www.camp-k.com/otona/camp/

*2 http://www.ycam.jp/greetings/index.html

*3 http://www.canvas.ws/

*4 http://www.bbc.co.uk/wales/audiovideo/sites/galleries/ pages/capturewales.shtml 
ることが，ワークショップの効果的な運用につながる と考えられる.

リフレクションは複数のファシリテータで行われる ため，時間軸に沿った多視点かつ協働できる枠組みが 有効である，近年，体験を記録し，自分や他人の体験 を追体験したり，新たな体験を生み出すことができる ような技術への期待が高まっており [6]，こうした技 術を用いて, 行為や対話といったイベントを時間配置 し再生する仕組みはリフレクションに利用可能であ る。また，協働で活動プロセスを構造的に扱う仕組み として, KJ法[7]のようなカードベースの構造配置に よる表現が有効である。そこで本論文では，ワーク ショップにおける活動を, 時間配置と構造配置による 表現を融合することによりリフレクションを支援する 仕組み“ワークショップリフレクター”を提案する。 ワークショップ中に記録した写真やビデオを時間配置 で表現する“タイムラインリフレクター”と，ワーク ショップ中のイベントをカードとして表現し構造配置 する“カードリフレクター”開発し, 組み合わせて活 動プロセスをリフレクションする仕組みを設計した。

\section{2 . ワークショップのリフレクションの支援}

\section{1 ワークショップの実例}

本論文で対象とするワークショップは, 室内で実施 される参加者数十人規模の参加体験型創造活動とす る。このようなワークショップでは, ファシリテータ と呼ばれるワークショップの設計者打よび司会者が テーマを設け, 参加者が作品を仕上げる過程を通じ て, 学習やコミュニケーションの活性化を罒る。ここ で, 多摩美術大学・情報デザイン学科の研究生らが開催

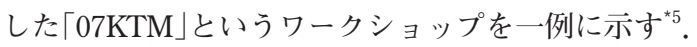
このワークショップでは,「子育てにやさしい町をつ くりたい」というテーマのもと, 中学生の「子育て」に 対する関心を高めることを目的に開催された。生徒た ちは, 自身の幼児期について調べ, 当時の写真や親か ら聞いた子どものころの様子を作品（図 1 ) として作成 し, 発表した。

ワークショップ中に記録した 1000 枚を超える写真 の多くは，生徒たちが作品を作成する様子や，参加者 同士やファシリテータとの対話の様子が中心的だっ た。このことから，ファシリテータが注目する点は， 作品が出来上がる過程, および参加者やファシリテー タの対話であると考えられる。ささらに、ファシリテー タにインタビューを行った結果, このようなワーク ショップのリフレクションに打いて, 以下の要素が必

*5 2007年 12 月 1 日付の北海道新聞朝刊に詳細が記載されてい る.

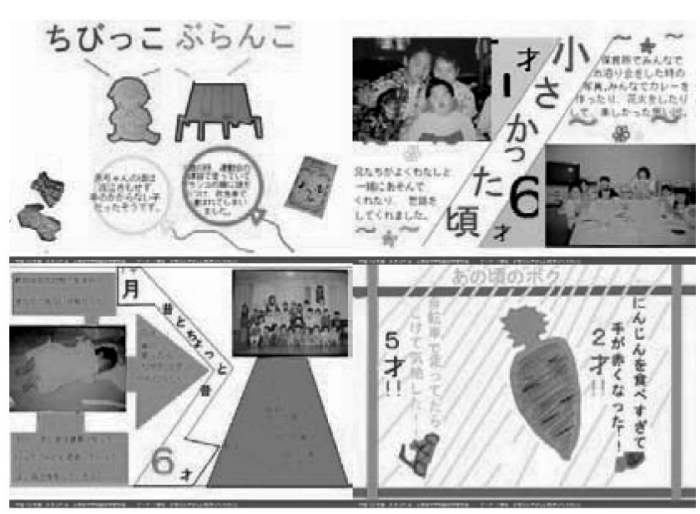

図 1 07KTM ワークショップの作品の一例

要であるとわかった.

・作品を作成する過程に対する註勫の付与

- 参加者の動きや対話に対する註勫の付与

- 同時に複数個所で起こるイベントの俯瞰

・ワークショップ中のイベントの切り出し

・時間的に離れているイベント間の関連付け

2.2 ワークショップのリフレクションシステムの全体 像

前述のリフレクションに必要な要素をふまえ, 我々 はワークショップにおける活動プロセスのリフレク ションの仕組みを図 2 のように考えた。この仕組みで は, ワークショップで記録されたコンテンツを時間配 置と構造配置により表現し組み合わせることで, 効果 的なリフレクションの実現を目指している.

まずカメラやマイク, ペンタブレットなどデバイス を用いてワークショップの活動プロセスを記録する。 次に, 記録したセンサデータの一部に対し, 前節で挙 げた, 註釈の付与や, イベントの俯瞰, イベントの切 り出し, イベント間の関連付けに必要なアノテーショ ンの付与を行う。ユーザの負荷を軽減するために, ア ノテーションを自動で付与できる仕組みが必要であ る.アノテーションの自動付与について, 本論文で開 発システムではまだ実現されていないが, 現時点の技 術で可能なデータの処理として, 我々は以下にあげる ものを想定している。

・文字が書かれた写真をスキャナで取り込んだデー タの文字認識

・タブレットのオンライン文字認識

・写真中の人の顔検出

・音響データからの音声認識

・センシングデータからのユーザの位置や向きの推 定 [8] 

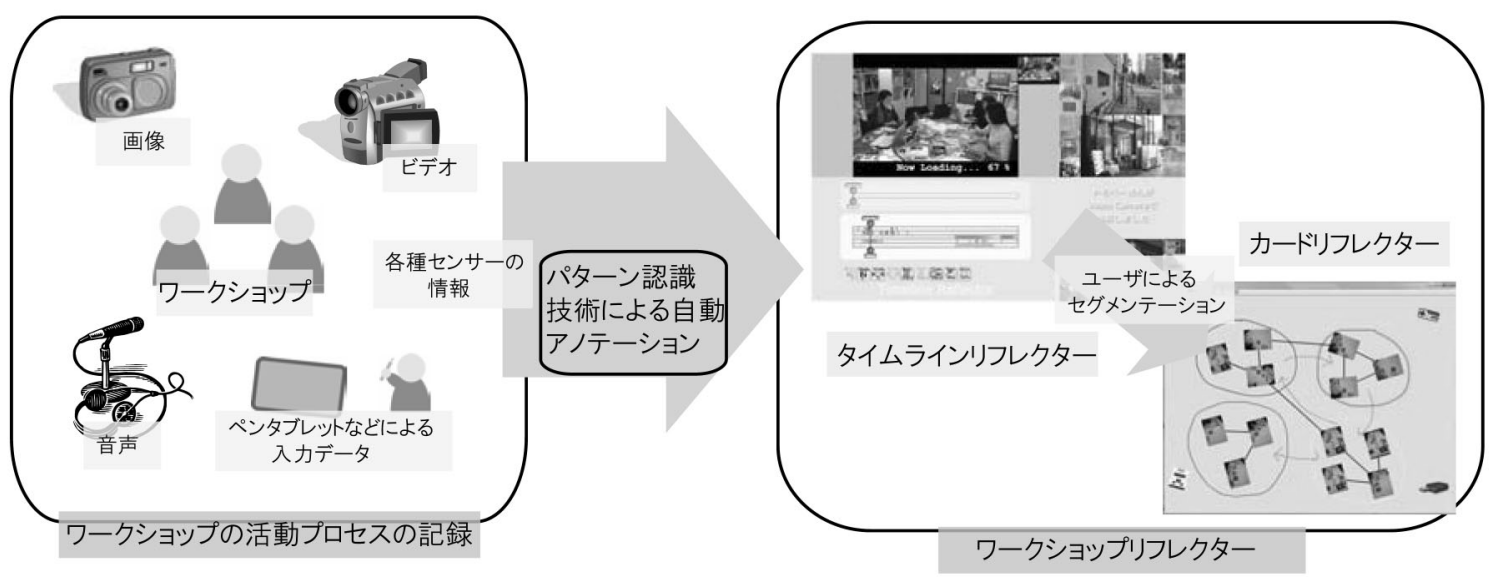

図 2 ワークショップの活動プロセスのリフレクションの全体像

ユーザはアノテーションが自動付与されたデータ， および映像や音声などのデータ自体を用いてリフレク ションを行う。まず，ユーザは“タイムラインリフレ クター”を用いて，ワークショップの活動をリフレク ションする。タイムインリフレクターは, ワーク ショップ中に記録された映像や音声などを時系列に配 置し，時間軸に沿ってデータを提示することにより， 活動を振り返ることができるッールである。ユーザ は, タイムラインリフレクター上で提示された映像や 音声から, ワークショップ中の特徴的なイベントを抽 出し，ユーザ自身の解釈や印象を加える。これによ り, ワークショップの活動プロセスがセグメンテー ションされる。

次に，ユーザは“カードリフレクター”を用いて活動 プロセスのリフレクションを行う。カードリフレク ターは, タイムラインリフレクターでセグメンテー ションされた活動プロセスをカード化し，2次元の フィールド上にカードを配置することや解釈や印象を アノテーションとして加えることによりリフレクショ ンを可能にするツールである。本論文では, カードリ フレクターとタイムラインリフレクターを組み合わせ てリフレクションするシステムをワークショップリフ レクターと呼ぶ.

\section{3. ワークショップリフレクター}

3.1 時間配置によるワークショップの表現 : タイムラ インリフレクター

ワークショップのリフレクションでは, 時間軸上で 特徴的な出来事を抽出できる必要があると考えられ る。そこでタイムラインリフレクターでは，ワーク ショップ中に記録した映像や音声などのデータを時系 列に配置し, 時間軸に沿ってデータに対し解釈や印象
などのアノテーションをユーザが付与することで特徴 的な出来事を抽出する. 以下にタイムラインリフレク ターに必要な機能をあげる。

\section{映像や音声などのデータの時系列表示}

タイムラインリフレクターでは, 時間をインデッ クスとして時系列でデータを配置することによ り，同時間に記録された映像や音声などを並列に 閲覧できる.

\section{解釈や印象などのアノテーションの付与} 映像や音声などのデータに対してテキストやフ リーハンドによるアノテーションを付与できる。 アノテーションは映像や音声などのデータ全体か データの一部(時間範囲や矩形範囲)に対し付与さ れる。これにより, 実世界の特徴的な活動を切り 出すことができ, ワークショップをセグメンテー ションできる。

\section{映像や音声などのデータの検索}

ユーザはタイムライン上に配置された映像や音声 のデータを, 時間をキーにして検索することがで きる.また，ユーザは自動アノテーションや付与 したアノテーションから映像や音声の検索ができ る。例えば，インデックスとして利用される時間 以外に, 文字情報や顔などの画像情報, 位置情報 に基づいたデータ検索ができる。

図 3 にタイムラインリフレクターのプロトタイプの 表示例を示す。タイムラインリフレクターのプロトタ イプでは, 動画や静止画, 音声, 位置情報などのデー タが記録された時間をもとにタイムラインを表示す る.また, 各データは並行して閲覧できるように表示 される。 


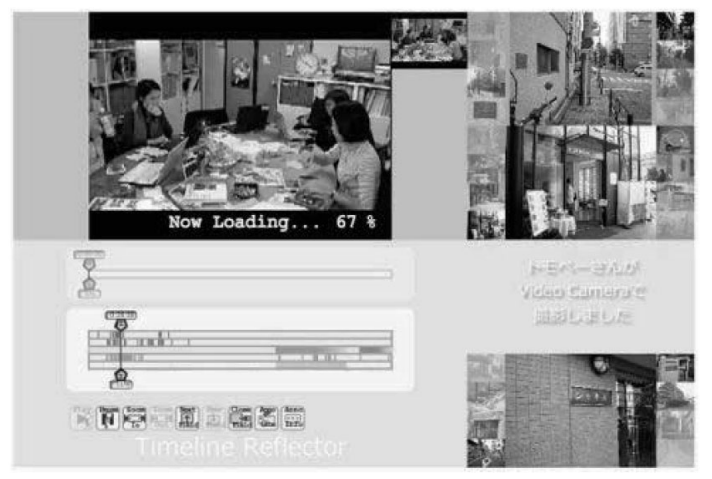

図 3 タイムラインリフレクターの表示の一例

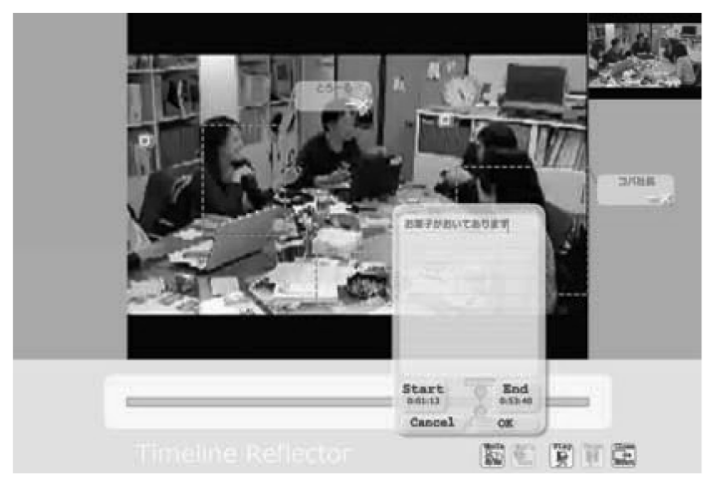

图４タイムラインリフレクター上でのアノテーション

このプロトタイプでは, タイムライン上からデータ を選択しクリックすると, 対応する動画や静止画が拡 大表示される．拡大表示されたデータに対し，矩形範 囲を指定することでアノテーションウィンドウが開 く.アノテーションウィンドウでデータや指定した範 囲に関する解釈や説明をテキストで入力できる。ま た，開始時間と終了時間を設定することにより，時間 範囲を指定することができる，時間範囲が指定された アノテーションは, タイムラインリフレクター上では 指定された時間範囲のみ表示される。アノテーション の様子を図 4 に示す．このアノテーションをもとに， カードリフレクター上にカードが生成される。

\section{2 構造配置によるワークショップの表現：カードリ フレクター}

タイムラインリフレクターによりセグメンテーショ ンされたワークショップの活動プロセスをリフレク ションするためには, さらにユーザの解釈や意罒を直 感的に付与できる仕組みが必要であると考えられる。

例えば, KJ法[7]のように, データやアイデアをカー ドとして 2 次元上のフィールドに表現し配置する手法
は，直感的な思考を行うために有効であると考えられ る。そこでユーザは，カードリフレクターを用いて， 計算機上の仮想的な机 (フィールド)の上で, 活動プロ セスをカードとして配置し, 関係のあるカードを近く に配置することや，アノテーションにより解釈や意図 をカードに加えることで, ワークショップの活動を構 造化し，直感的な思考を行うことができるだろう，以 下にカードリフレクターに必要な機能をあげる。

\section{新しいカードの作成}

タイムラインリフレクターを用いて，ユーザは活 動プロセスをセグメンテーションする。このセグ メンテーションした活動プロセスは, カードリフ レクター上ではカードとして表現される。それぞ れのカードはワークショップ中に記録された映像 や音声などのセンサーデータを持つ.

カードの移動とグルーピング

ユーザはカードリフレクターのフィールド上で カードを直感的に操作できる，例えば，関連性の 強い活動プロセスのカードを近くに移動させるこ とができる，また，カードの角度を変化させるこ とにより, 対面テーブルなどで用いてリフレク ションする場合に対面にいるユーザにカードを提 示することできる。ささらに, 活動プロセスを構造 化するためにカードのグルーピングは必要である と考える，グルーピングは関係するカードを円で 囲むといった簡単な動作で実現される.

\section{アノテーションの追加}

活動プロセスの解釈や意図として, ユーザはテキ ストやリンク，描画アノテーションを付与するこ とができる。テキストアノテーションと描画アノ テーションは, カード全体やカードの一部に対し て付与される。関係あるカードにリンクアノテー ションを用いることにより, ワークショップの活 動プロセスはネットワーク状になり，ユーザは構 造的に俯瞰することができる。 また，フリーハン ドによる描画アノテーションは活動プロセスへの 解釈を直感的に付与することができる。ささに カードが配置されているフィールド（仮想的な机） へも直接描画アノテーションを加えることによ り，ユーザは活動プロセスの構造化を支援する情 報を付与できる。

カードやアノテーションの検索

ユーザが目的のカードを容易に操作するために,

カードやアノテーションの検索が必要である.

ユーザはテキストのキーワードによる検索だけで なく, パターン認識技術を用いた手書きの描画に 
よる検索や, リンク構造に基づくカードの検索も 必要である。

図 5 にカードリフレクターのプロトタイプの表示例 を示す。カードリフレクターの入力操作はペンタブ レットを用いて行う。リフレクション時の操作はペン タブレットをユーザが共有して入力する。ユーザはそ れぞれIDを持ったペンにより入力を行うので，全て の操作について，操作を行ったユーザを特定すること が可能である。ユーザはカードの中心をポイントしド ラッグすることでカードを操作することができる．ま た，カードの四隅をポイントしドラッグするとカード を回転することができる。また，フィールドに対し困 形や文字をフリーハンドで描画することができる.

カードにリンクアノテーションを付与するには， フィールド上のカードを 2 つ選ぶ。まず，ユーザはリ ンクの始点となるカードを選択しポイントする，次に リンクの終点となる別のカードを選択しポイントす

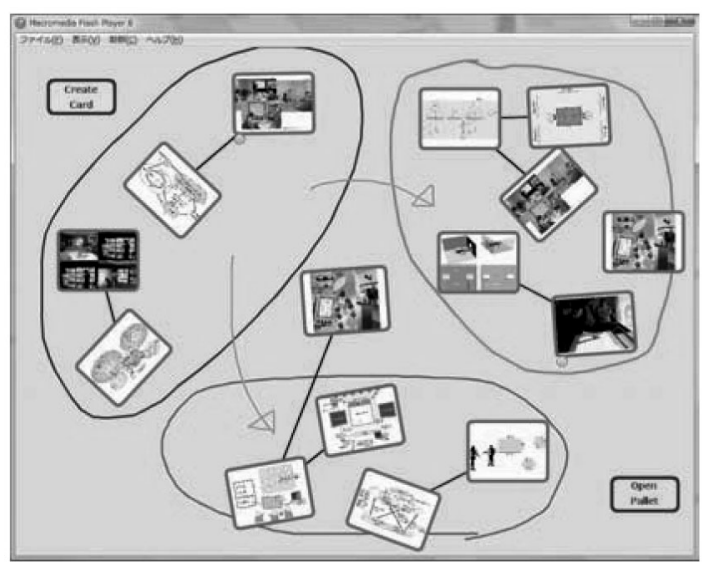

図 5 カードリフレクターの表示の一例

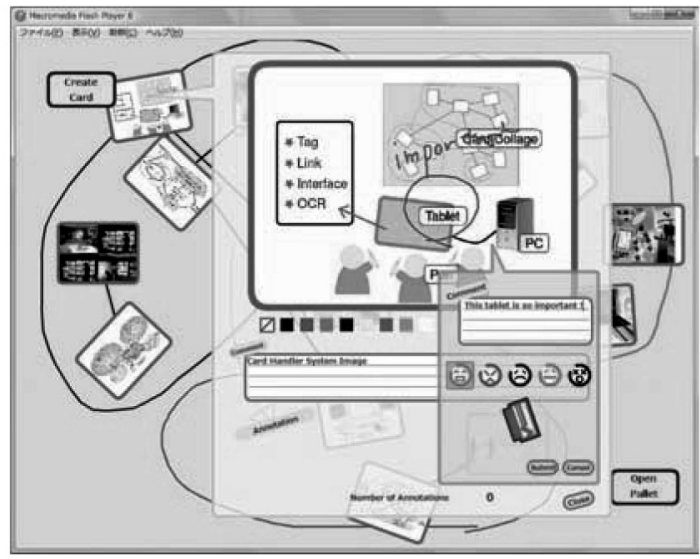

図 6 カードへのアノテーションの一例
る.リンクの始点と終点となるカードを確認し, リン クを付与する場合には終点となるカードをもう一度ポ イントするとこれらのカードにリンクが付与される.

図 6 にプロトタイプに打けるカードのアノテーショ ン付与ウィンドウの例を示す.フィールド上のカード をダブルクリックするとアノテーション付与ウィンド ウが開く.アノテーションウィンドウでは, カードに 直接描画することで描画アノテーションを付与するこ とやカード全体や一部に対してテキストアノテーショ ンを付与することができる.

\section{4. 実験と結果}

ワークショップのリフレクションッールとして, 本 論文で提案するワークショップリフレクターの特徵を 示すため, タイムラインリフレクターとカードリフレ クターによるリフレクション実験を行った。この実験 では，活動を表すコンテンツを時間配置により表現し たタイムラインリフレクターと, 構造配置により表現 したカードリフレクターのリフレクションに打ける効 果の違いを明確にするのが目的である。

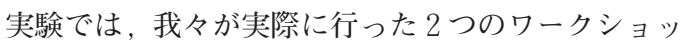
プをテーマとして用意し, テーマA，テーマBとし た。そして，ワークショップに参加したファシリテー 夕(男性 6 人, 女性 2 人の計 8 人) を 2 グループに分 け，各テーマについてそれ元れのリフレクターを用い てリフレクションを行った。両方のリフレクターの利 用方法の詳細を説明した後, 各被験者にペンタブレッ 卜入力用のペンを配布し，それぞれのツールにおける 操作履歴を記録した。各被験者は同じグループのメン バーと同時に同じ画面を見て, 話し合いながらリフレ クションを行った。テーマへの依存を考虑し，各グ ループのリフレクションのテーマと利用ッールを表 1 に示す。また，リフレクション終了後にカードリフレ クターとタイムラインリフレクターのリフレクション 効果や使用感に関するアンケートを行った。

\section{1 実験結果と考察}

表 2 にカードリフレクターのフィールド打よびカー ドへのアノテーション数とタイムラインリフレクター の画像へのアノテーション数とリフレクションにか かった時間を示す。なお，Cはカードリフレクター， Tはタイムラインリフレクターを示す。テーマA，

表 1 リフレクションのテーマと利用ツール

\begin{tabular}{l|c|c} 
& カード & タイムライン \\
\hline グループ1 & テーマ $\mathrm{A}$ & テーマ $\mathrm{B}$ \\
グループ2 & テーマB & テーマ $\mathrm{A}$ \\
\hline
\end{tabular}


表 2 アノテーション数とリフレクションにかかった 時間

\begin{tabular}{c|cc|c|c|c} 
& \multicolumn{3}{|c|}{ アノテーション数 } & \multicolumn{2}{c}{ 時間 (秒) } \\
\hline & \multicolumn{2}{|c|}{$\mathrm{C}$} & $\mathrm{T}$ & $\mathrm{C}$ & $\mathrm{T}$ \\
& フィールド & カード & 画像 & & \\
\hline Group A & 114 & 6 & 15 & 1804 & 1046 \\
\hline Group B & 89 & 0 & 12 & 2877 & 471 \\
\hline
\end{tabular}

テーマBともカードリフレクターによるアノテーショ ン数はタイムラインリフレクターを上回った。一方, 画像に対し付与されたアノテーションの数はタイムラ インリフレクターがカードリフレクターを上回った。

カードリフレクターによりリフレクションを行った 結果得られたカードの最終的な配置の例として, グ ループ 2 のカードリフレクターの様子を図 7 に示す. これはグループ 2 のメンバーが, 同じ画面を見ながら 配置, 記入したものである。またツール利用後のアン ケートでは, リフレクターに対し以下のような意見が 得られた。

・カードリフレクターではカードの関係を構造的に 俯瞰でき, 全体をまとめたリフレクションができ る。

・カードを並び替えて構造的に理解するため, カー ドへコメントする機会が少なくなるが，その替わ りにフィールドへのアノテーションの機会が多く なる。

・カードリフレクターでは構造的な俯瞰により, 活 動プロセスを振り返る上で不足している要素が明 確になる。

・タイムラインリフレクターでは活動の変遷を俯瞰 することが容易である。

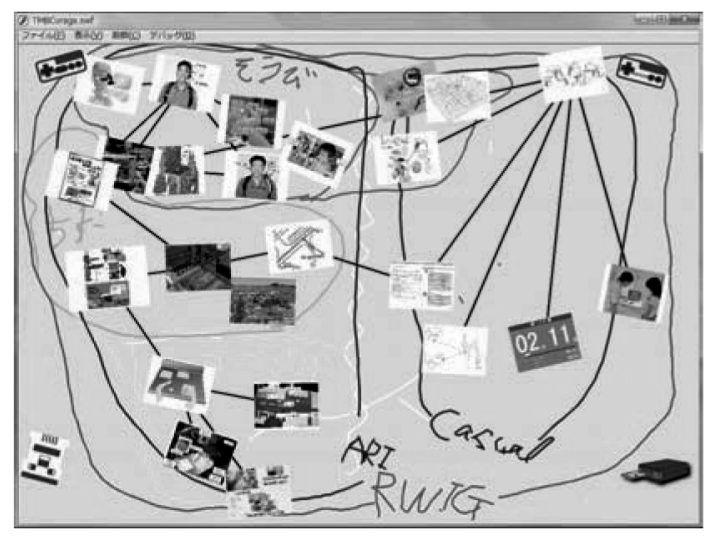

図 7 カードリフレクターの最終的な配置
評価実験に打いて，タイムラインリフレクターで は, シーケンシャルにデータが提示されるので提示さ れているデータに集中してリフレクションでき, 個々 の活動プロセスに対するコミュニケーションが活性化 するシーンが見られた。一方カードリフレクターで は, 活動プロセス全体を通じてカードを配置し, リフ レクションを行うシーンが見られた。

評価実験では, カードリフレクターを用いて, グ ループ 1 , グループ 2 ともにフィールドへのアノテー ションが集まった. カードの移動は 6 秒に 1 度の間隔 で行われていた。 また, リフレクション時間はタイム ラインリフレクターに比べカードリフレクターのほう が長かった。これはユーザがカードの移動やグルーピ ングすることで, カードを様々な視点によりカードを 構造化しようとしていたことを示している。

タイムラインリフレクターでは, 活動プロセス自体 に対しアノテーションが付与される様子がよく見られ た．被験者のコメントにあるように，タイムラインリ フレクターを通じて活動の変遷を見つけることができ たと考えられる.

この実験から, 時間配置による表現はプロセスの変 遷のような時間的な変化を詳細に捉える場合に役立つ ことがわかった。また，構造配置による表現では， ユーザはカードの移動やグルーピングを通じ, 活動プ ロセスの関係性や構造化を考え振り返る場合に役立つ ことがわかった。

本論文では，参加体験型創造活動であるワーク ショップを対象にしている。このようなワークショッ プでは, 時間に沿って作品が創造される過程をリフレ クションするために記録した動画を用いることが多 い，そのため，時系列にイベントを並べた表現はリフ レクションに必要であると考えられる。一方，ワーク ショップで起こるイベント間には, 因果がある, 同種 である，など様々な関係が存在する。これらの関係は 時系列に依存せず構造に処理することで, 活動プロセ スの理解が深まるだろう。また, 評価実験により, 時 間配置と構造配置はそれぞれ異なった特徴を持つこと がわかった。時系列による可視化とカードによる可視 化を併用することで, 時間配置と構造配置の 2 つの性 質を活用することができ，より効果的なリフレクショ ンが実現できると考えられる。

\section{5 . おわりに}

本論文では, 実世界のワークショップのリフレク ションにおいて, 時間配置と構造配置による表現を融 合した仕組み“ワークショップリフレクター”を提案し た。 また, ワークショップリフレクターの有効性を示 
すため，プロトタイプを開発し評価実験を行った。そ の結果，時間的な変化を詳細に捉える場合には，時間 配置による表現の方が多く利用され，要点を捉えた カードを俯瞰して活動全体の関係や構造について振り 返る際には構造配置による表現が役立つことが確認で きた。

今後の課題として, 本論文で実験に用いたプロトタ イプシステムで実装されていない検索機能を実装する ことがあげられる。そして評価実験と開発を繰り返す ことで，直感的なインタフェースを持つッールとして デザインする必要がある。

\section{謝辞}

本研究の一部は, 科学技術振興事業団「JST」の戦略 的基礎研究推進事業「CREST」に打ける研究領域「デジ タルメディア作品の制作を支援する基盤技術」の研究 課題「情報デザインによる市民芸術創出プラット フォームの構築」の支援により行いました。

\section{参 考 文 献}

［1］中野民夫. ワークショップー新しい学びと創造の場. 岩波新書, 2001.

[2] Robert Chambers. Participatory Workhops : A Sourcebook of 21 Sets of Ideas and Activities.
Earthscan Pubns Ltd, 2002.

[ 3 ] 三輪和久, 石井成郎. 創造的活動への認知的アプロー 于. 人工知能学会誌, Vol.19, No.2, pp.196-204, 2004.

[ 4 ] C. Cornoldi. The impact of metacognitive reflection on cognitive control, G. Mazzoni and T. O. Nelson., eds. Metacognition and Cognitive Neuropsychology : Monitoring and Control Processes. Lawrence Erlbaum Associates, Inc. New Jersey, 1998.

［5］中野民夫.ファシリテーション革命参加型の場づくり の技法。岩波アクティブ新書, 2003.

[6]角康之.映像と音声のコラージュによる体験のアウェ アネス支援。日本バーチャルリアリティ学会誌, Vol.10, No.2, pp.83-87, 2005.

［７］川喜田二郎. 発想法一創造性開発のために.中公新書, 1967.

[ 8 ] Takuichi Nishimura, Yoshiyuki Nakamura, Hironori Tomobe, Takeshi Kurata, Takashi Okuma, and Yutaka Matsuo. Location estimation using auditory signal emitted and received by all objects. In Proc. of INSS '07, 2007.

(2009年 3 月31日 受付)

(2010年 3 月 3 日 採録)

[問い合わせ先 ]

干113-8656 東京都文京区弥生2-11-16

総合研究機構

友部 博教

TEL : 03-5841-7672

E-mail : tomobe@biz-model.t.u-tokyo.ac.jp 


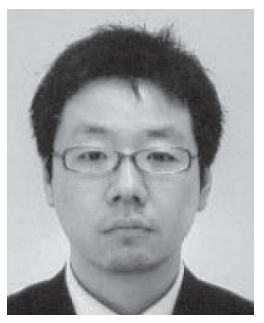

\section{皆部博教 [非会員]}

1999 年東京大学工学部電子情報工 学科卒業. 2001 年東京大学大学院工 学系研究科電子情報工学専攻修士課程 修了。 2004 年東京大学大学院情報理 工学系研究科電子情報学専攻博士課程 修了・博士 (情報理工学)。2004 年名 古屋大学 21 世紀 COE「社会情報基盤 のための音声 ·映像の知的統合」博士 研究員. 2007 年産業技術総合研究所 · 特別研究員. 2008 年 6 月より東京大 学大学院工学系研究科総合研究機構 ノベーション政策研究センター助教. Web 編集エンジンや知識の構造化 . 俯瞰に関する研究に従事.

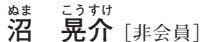

2002 年横浜国立大学教育人間科学 部マルチメディア文化課程卒業. 2004 年同大学院環境情報学府博士前 期課程修了. 2007 年, 総合研究大学院 大学情報学専攻博士後期課程修了. 同 年より, 東京大学先端科学技術研究セ ンター研究員. 社会実践を指向した AI システム, コミュニティでの情報 共有システム,ならびに複数ユーザの 創造活動支援システムの研究に従事. 情報処理学会, 電子情報通信学会, 人 工知能学各会員. 博士 (情報学).

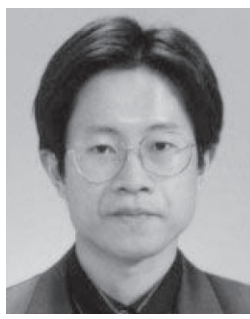

茜村奇拓一俳会員]

1992 年東京大学工学系大学院修士 (計測工学) 課程修了. 同年, NKK (株) 入社. $\mathrm{X}$ 線, 音響・振動制御関係の研 究開発に従事. 1995 年技術研究組合 新情報処理開発機構つくば研究センタ に出向. 2001 年独立行政法人産業技 術総合研究所サイバーアシスト研究セ ンターに所属, 2005 年同情報技術研 究部門に所属, 2009年NECに出向, 現 在に至る. 博士 (工学). 時系列デー 夕検索・認識, 実世界情報支援に興味 を持つ. 電子情報通信学会, 情報処理 学会, ヒューマンインタフェース学会 各会員.

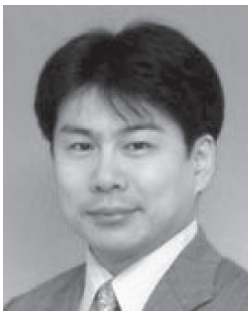

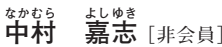

1994 年神奈川大学理学部情報科学 科卒業。1996 年電気通信大学大学院 情報システム学研究科博士前期課程修 了. 1997 年同大学院博士後期課程退 学. 同年同大学院助手. 2002 年産業技 術総合研究所サイバーアシスト研究セ ンター特別研究員. 2004 年同所情報 技術研究部門へ改組. 2005 年同所同 研究部門研究員. ロケーション・ア ウェアな情報支援システムの研究に従 事. 博士 (工学).

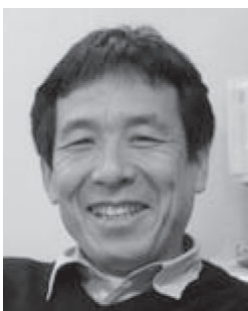

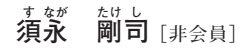

1989年より多摩美術大学, 1995-96 年スタンフォード大学客員研究員, 1988-89 年イリノイ工科大学研究員, 学術博士 1987 筑波大学, 1985-89 年 筑波大学芸術学系助手, 筑波大学大学 院修了. 主な共著書, 「情報デザイン」 グラフィック社 2002 ,「情報とメディ アー現代の教育 8 」岩波書店 1998 , 「新工学知 -3 技術知の射程」東京 大学出版会 1997 , 訳書「ヒューマンイ ンタフェースの設計方法」マグロウヒ ル出版 1994 など. 日本デザイン学会, 日本認知科学会会員, ヒューマンイン タフェース学会会員. 


\section{Reflecting Processes of Human Activities on Workshops by Combining Timeline - based and Card - based Representation}

by

\section{Hironori TOMOBE, Yoshiyuki NAKAMURA, Kousuke NUMA, Takeshi SUNAGA and Takuichi NISHIMURA}

\section{Abstract :}

In relation to workshops, which are events designed for participatory learning and creative endeavors in groups, repeated reflections upon the activities on the workshop are important for participants and organizers. We propose a reflection-assistance method called "Workshop Reflector", which is a seamlessly combined system of "Timeline Reflector" and "Card Reflector." Timeline Reflector can support workshop reflection with timeline-based representation. Card Reflector can facilitate workshop reflection in a different manner than that of a conventional timelinebased representation. The cards are segmented by users from the timeline contents as noticeable events. We examined the combined use of Card Reflector and Timeline Reflector by developing a prototype.

Keywords : reflection, workshop, activity support, card-based tool, timeline-based tool

Contact Address : Hironori TOMOBE

Institute of Engineering Innovation

2-11-16, Yayoi, Bunkyo-ku, Tokyo, JAPAN

TEL : 03-5841-7672

E-mail : tomobe@biz-model.t.u-tokyo.ac.jp 